\title{
The Great Western Railway
}

\author{
Harold W. Noonan ${ }^{1}$
}

Received: 16 January 2020 / Revised: 16 June 2020 / Accepted: 24 August 2020/

Published online: 2 September 2020

(C) The Author(s) 2020

\begin{abstract}
In On The Plurality of Worlds Lewis presents the case of the Great Western Railway as a candidate counter-example, along with the usual suspects, to the thesis that two things cannot be in the same place at the same time. Typically, pluralists or many-thingers, i.e., those who reject the thesis, point to modal or historical or aesthetic differences to justify their judgement of non-identity. Lewis's aim to is to show the inadequacy of this justification, at least as regards modal differences, by considering a case in which it clearly fails, in which the judgement of non-identity so based is incredible, and hence to make it evident that in all such cases the appeal to modal differences is insufficient. What makes the case of the Great Western Railway special is that it is a purely spatial example, as Lewis emphasises. In what follows I set out the example and try to make it clear that, as Lewis says, for this reason a judgement of non-identity based on an appeal to modal differences is incredible. Then I give another example, easier to understand, I think, which makes the same point, inspired by Russell's famous joke about the irate yacht owner.
\end{abstract}

Keywords The great Western railway $\cdot$ Lewis, modality $\cdot$ Identity $\cdot$ Inconstancy

In On The Plurality of Worlds (1986: 248 ff.) Lewis presents the case of the Great Western Railway as a candidate counter-example, along with the usual suspects, the statue and the clay, Tib and Tibbles and so on, to the thesis that two things cannot be in the same place at the same time. Typically pluralists or many-thingers, i.e., those who reject the thesis, point to modal or historical or aesthetic differences to justify their judgement of non-identity. Lewis's aim to is to show the inadequacy of this justification, at least as regards modal differences, by considering a case in which it clearly fails, in which the judgement of non-identity so based is incredible, and hence to make it evident that in all such cases the appeal to modal differences is insufficient. What makes the case of the Great Western Railway special, and so convincingly not a case of

Harold W. Noonan

harold.noonan@nottingham.ac.uk

1 Department of Philosophy, University of Nottingham, Nottingham NG72RD, UK 
two things in the same place at the same time differing solely in modal respects, is that it is a purely spatial example, as Lewis emphasises, in which the ground for a judgement of non-identity can only be a claimed modal difference (unlike merely temporary coincidence cases, like that of Tib and Tibbles), but in which the modal difference appealed to cannot be a difference in capacities for change over time (as in cases like the permanently coincident statue and clay, which pluralists claim to be nonidentical because the clay could have been rolled into a ball and not destroyed, whereas the ball could not have survived that change). But there has been little discussion of it or appreciation of its significance, maybe because to fully understand it one has to read O.S. Nock's three volume work History of the Great Western Railway (1967). In what follows I set out the example and try to make it clear that as Lewis says, a judgement of non-identity based on modal differences alone is in this case incredible. Then I give another example, easier to understand, I think, which makes the same point, inspired by Russell's famous joke about the irate yacht owner.

The Great Western Railway could have absorbed two other railways early on, in 1845: the Bristol and Gloucester and the Birmingham and Gloucester. It didn't. So the Bristol-Gloucester-Birmingham line did not become a part of it. In the 1923 regrouping of railways a new railway company was brought into existence, also named the Great Western Railway, which had as constituents the lines previously parts of the old (now no longer existent) Great Western and the leading Welsh lines. This new railway company did not have, and never had, the Bristol-Gloucester-Birmingham line as a part. But it might have had. It would have had if things had gone differently in 1845 (78 years before it came into existence). (And let us add to Lewis's story, to absolutely exclude any strife about temporal parts, that in 1923, immediately after the contracts were signed and the new Great Western came into being, the Earth was invaded by Martians and everything destroyed.)

Now, Lewis says, let us fix the reference of the term 'GWR-minus' by the description 'the new Great Western as it actually was in 1923 (from the moment it existed), without the Bristol-Gloucester-Birmingham line'. Let us fix the reference of the term 'GWR' by the description 'the new Great Western'. Let GWR-plus be the sum of GWR-minus and the missing line. GWR is GWR-minus. ${ }^{1}$ What might have happened to it? It is GWR, so it might have been greater. It would have been - in fact, it would have been GWR-plus - if things had gone differently in 1845. But it is GWR-minus. So it could not have been greater. Rather, if things had gone differently in 1845 it would have been merely part of the new Great Western in 1923. Pluralists might respond that this shows that GWR is not GWR-minus. But it is incredible to say on this basis that GWR is not GWR-minus, that there are two instantaneous, wholly material things in the same place at the same time in 1923 differing only in how they could have been at that time. So Lewis appeals to the inconstancy of modal predication to explain away the apparent non-identity. And if it can be brought in here, it is available to deal with all putative examples of non-identity justified by appeal to modal differences. Of course, in other cases of putatively all-time coincident non-identical things pluralists can appeal to other apparent differences, e.g., aesthetic ones. So Lewis

\footnotetext{
${ }^{1}$ Someone might say that two terms related as 'the new Great Western' and 'the new Great Western blah blah' must have the same reference. I do not appeal to this in the argument for the incredibility of denial of identity in the next paragraph.
} 
has not provided a general recipe for responding to any pluralist argument. But given the incredibility of the judgement of non-identity based on the assertion of a modal difference in this case he has shown that modal differences alone cannot always justify non-identity judgements, and if not always, how ever? ${ }^{2}$

The example of the Great Western is difficult to follow. Here is a simpler one. Russell tells the story of the yacht owner who when told 'I thought your yacht is larger than it is' replies: 'No, it isn't larger than it is'. Suppose a millionaire wants a yacht built to his own specification. He plans a two decker. Work goes well and a sea-worthy vessel is constructed complete up to the first deck with only the second deck to be added (which has been prepared previously and has only to be bolted on). Then the millionaire is financially ruined. Construction stops. Then the Martians invade and everything is destroyed. Let 'Y-minus' be a term whose reference is fixed by the description 'the yacht as it actually is, without the second deck'. Let ' $Y$ ' be a term whose reference is fixed by the description 'the yacht'. Let Y-plus be the structure composed of $\mathrm{Y}$-minus and the missing deck. $\mathrm{Y}$ is $\mathrm{Y}$-minus. But $\mathrm{Y}$ might have been larger. It would have been if the millionaire had not suffered financial ruin. Y-minus would not have been larger then, however; it would rather have been merely a proper part of Y. It is incredible to suppose that in the dry dock when the workmen down tools there are two numerically distinct material objects which are wholly coincident differing only in this modal respect. Identity has to be accepted and the inconstancy of modal predication appealed to. Again there is no argument here that in other cases nonidentity cannot be established in cases of coincidence by appeal to apparent differences in non-modal, e.g., aesthetic, differences (though are there not such apparent differences here, e.g., is not Y-minus a beautiful example of a hull-lower deck structure, whilst $\mathrm{Y}$ is an ugly, incomplete thing?). But the example does, I think, like Lewis's, establish that appeal to modal differences cannot always suffice alone to justify nonidentity.

It should be noted though that the example is not exactly the same in structure as Lewis's. In the case of the Great Western it comes into existence instantaneously when the contracts are signed in 1923, lacking the missing line, and if things had gone differently in 1845 it would have come into existence instantaneously in 1923, at the same moment, with the missing line as a part. In the case of the yacht, since construction takes time it would not have come into existence at the same time as a two-decker as it actually did as a one-decker. The extra structure would have been added afterwards. Perhaps this detracts from persuasiveness of the identity claim. But we can imagine the case differently. Suppose the millionaire saw financial ruin as a possibility so told the construction team to work slowly. If it hadn't been coming, however, he would have had no indication of it, and would then have told them to work more quickly. So in the counterfactual situation the two-decker would have been completed when the one-decker actually was. There are, of course, still differences

\footnotetext{
2 The pluralist can respond by accepting the identity in this case and rejecting the modal intuitions pointing to non-identity, whilst still endorsing e.g., the non-identity in the clay/statue case on the basis of the intuition that the clay could have been rolled into a ball without being destroyed, though the statue could not. Then he needs to explain why. How, from his point of view, can it matter that the example of GWR involves instantaneous rather than non-instantaneous, but still permanent, total coincidence? Alternatively, he can accept the identity and the modal intuitions but say that these modal predications are inconstant. Then he has to explain which modal predications are constant and what the difference is.
} 
between this case and Lewis's. But I hope this discussion has made it clear that by considering purely spatial examples, as Lewis suggests, in which the alleged modal difference must be restricted to how the putatively non-identical things could have differed at a particular moment of time, the case for the inconstancy of modal predication can be made irresistible, since if the inconstancy of modal predication is rejected an appeal to any modal difference must suffice to justify a claim of nonidentity. ${ }^{3}$

Open Access This article is licensed under a Creative Commons Attribution 4.0 International License, which permits use, sharing, adaptation, distribution and reproduction in any medium or format, as long as you give appropriate credit to the original author(s) and the source, provide a link to the Creative Commons licence, and indicate if changes were made. The images or other third party material in this article are included in the article's Creative Commons licence, unless indicated otherwise in a credit line to the material. If material is not included in the article's Creative Commons licence and your intended use is not permitted by statutory regulation or exceeds the permitted use, you will need to obtain permission directly from the copyright holder. To view a copy of this licence, visit http://creativecommons.org/licenses/by/4.0/.

\section{References}

Lewis, D. (1986). On the plurality of worlds. Oxford: Blackwell.

Nock, O.S. (1967). History of the great Western railway, volume III. Ian Allan.

Publisher's Note Springer Nature remains neutral with regard to jurisdictional claims in published maps and institutional affiliations.

\footnotetext{
${ }^{3}$ It is probably wise to emphasise the modesty of this conclusion. It is not an argument for counterpart theory, as Lewis emphasises: 'It is well for my preferred theory ... that it has no trouble making representation de re come out inconstant. But ... its leading rivals ... provide for inconstancy with equal ease' (1986:259)
} 